\title{
Article
}

\section{Improving water resources management using different irrigation strategies and water qualities: Field and modelling study}

Afzal, Muhammad, Battilani, A., Solimando, D. and Ragab, R.

Available at http://clok.uclan.ac.uk/33888/

Afzal, Muhammad, Battilani, A., Solimando, D. and Ragab, R. (2016)

Improving water resources management using different irrigation strategies and water qualities: Field and modelling study. Journal of Agricultural Water Management, 176 . pp. 40-54. ISSN 0378-3774

It is advisable to refer to the publisher's version if you intend to cite from the work. http://dx.doi.org/10.1016/j.agwat.2016.05.005

For more information about UCLan's research in this area go to http://www.uclan.ac.uk/researchgroups/ and search for <name of research Group>.

For information about Research generally at UCLan please go to http://www.uclan.ac.uk/research/

All outputs in CLoK are protected by Intellectual Property Rights law, including Copyright law. Copyright, IPR and Moral Rights for the works on this site are retained by the individual authors and/or other copyright owners. Terms and conditions for use of this material are defined in the policies page. 


\title{
Water use efficiency in agriculture under different irrigation strategies and climate change scenarios
}

\author{
Afzal, M. ${ }^{1}$, Battilani, A. ${ }^{2}$, Solimando, D ${ }^{2}$, R. Ragab ${ }^{1}$
}

\begin{abstract}
The aim of this paper was to investigate the effects of two different irrigation strategies, regulated deficit irrigation, RDI and partial root drying, PRD using surface freshwater (SW) and brackish treated waste water (TWW) for tomato for the year 2015. The field experiment was carried at CER experimental farm in the Bologna Italy. The field experiment showed close crop yields under the two irrigation strategies and two water qualities. The SALTMED modelling results illustrated that the model can simulate reasonably well the soil moisture content, soil salinity, dry matter and final crop yields. Both field observations and model results indicated that water saving irrigation strategies like PRD (Partial Root-zone Drying) and RDI (Regulated Deficit Irrigation) almost produced similar crop yields and total dry matter with freshwater as with treated waste water irrigation. However, PRD used between 15 to $17 \%$ less water than RDI excluding the rainfall. Water productivity as was calculated from rainfall and irrigated water was slightly higher for the PRD in comparison with the RDI irrigation strategy. Such PRD irrigation strategies have huge potential to reduce cost and water consumption that could be used to irrigate more land to meet the future food demand.
\end{abstract}

Key words: SALTMED model; Regulated Deficit Irrigation, RDI; Partial Root-zone Drying PRD; soil moisture; soil salinity, irrigation; Potato, Maize, yield

\footnotetext{
${ }^{1}$ Centre for Ecology and Hydrology (CEH), Wallingford, United Kingdom

${ }^{2}$ Consorzio di Bonifica di secondo grado per il Canale Emiliano Romagnolo - CER, Bologna, Italy
} 


\section{Introduction}

Food demand across the world has been significantly increased which has resulted in increased water demand for the growing population. Irrigation water has the main share of the fresh water consumption. Around 280 million hectares of agricultural land is irrigated using freshwater that provides around $60 \%$ of total food production worldwide (Tilman et al., 2002). About half of the world's food is produced on irrigated land and irrigated water accounts for over two thirds of the global water consumption (Letey et al., 2011). The agricultural water consumption has increased fivefold since the 1940's and now accounts for $70 \%$ to $80 \%$ of the world fresh water use (Ragab et al., 2015). It will further increase in future due to the increase in the food demand for the growing world's population. By 2050, food demand is expected to double in comparison to the current global food demand which poses a threat for the sustainability of the both food production and the natural ecosystem (Tilman et al., 2002). The availability of the water resources is not only under threat due to the increase in water demand for agriculture but also due to climate variability. Therefore, the gap between water supply and demand is expected to increase. In several parts of the world, climate variability is expected to reduce water availability for agriculture and subsequently for crop yield. Therefore, it is very important to increase the crop productivity as the world population is expected to reach 9 billion and food production needs to be doubled by 2050 (Ragab et al., 2015).

Water productivity can be increased by applying different water saving techniques in agriculture including drip irrigation. In this study water saving techniques were applied on most water demanding crops in the area using two types of irrigation water: freshwater and treated waste water. The impact of water saving irrigation techniques (RDI-regulated deficit of irrigation; PRD-partial root drying) were assessed as well in combination with irrigation water salinity effects both on technologies and crop response to irrigation. The subsurface drip irrigation strategies were applied as RDI and PRD irrigation to allow significant amount of water savings. The RDI strategy aims to use water stress to control vegetative and reproductive growth. The principle behind PRD-irrigation is to alternatively let one part of the root system to expose soil drying, while the other part is irrigated, in order to keep the leaves hydrated. This triggers hormonal signal including abscisic acid (ABA) that partly close stomata and modify growth and hereby improve water efficiency. The results from field experiment were used to provide data for the modelling study. 
Integrated crop-soil-water models have been proven to be effective tools for water resources management in agriculture. These models allow to study the impact of using different water resources and qualities, including freshwater, treated waste water and saline/brackish water on crop yield and soil productivity. Considering the pressure on water resources, different drought and salinity tolerant crops need to be considered. The SALTMED model developed by Ragab (2002) has been widely used for different irrigation and fertigation systems for different crops. This model has been successfully applied in different parts of the world. This model has been used in Egypt and Syria for tomato crop (Ragab et al., 2005a, 2005b), for sugarcane in Iran, (Golabi et al.2009), for chickpea in Portugal under both dry and wet conditions, (Silva et al. 2013), for Quinoa in Morocco, (Hirich et al. 2012 and Fghire et al. 2015), for quinoa in Denmark, (Razzaghi et al. 2013), for quinoa in Italy, (Pulvento et al. 2013), for amaranth in Italy, (Pulvento et al. 2015a), for sweet pepper in Antalya, Turkey, (Rameshwaran et al. 2015), and for Legumes in Syria, (Arslan et al 2015). The model was also applied with climate change scenario by Pulvento et al. (2015b) to predict the impact of climate change on the length of the growing season of amaranth in Italy. They predicted a shorter season from 114 days for actual climatic condition (2009-2010) to 98 days for the high emission scenarios in 2095. This study also projected a decrease in grain yield.

The aim of this study is to quantify the effects of different deficit irrigation strategies (RDI and PRD) using fresh water and treated waste water on soil moisture and salinity distribution, total dry matter and crop yield of potato and maize in Bologna, Italy through field experiments and SALTMED model application.

\section{SALTMED Model}

SALTMED new version, Ragab et al. (2015) which accounts for subsurface irrigation, partial root drying (PRD) or deficit irrigation, fertigation, soil nitrogen fertiliser application and plant nitrogen uptake, biomass and dry material production and nitrate leaching was used in this study. A detailed description of the SALTMED model is provided in (Ragab, 2002, Ragab et al., 2005a, Ragab, 2015, Ragab et al., 2015) and some of the above mentioned literature.

\section{Materials and Methods}

A two year crop rotation with high irrigation intensity was grown on silty-clay soil at Consorzio Bonifica CER' experimental farm “Azienda Marsili”, located in Mezzolara di Budrio 
(Bologna, Italy), Po valley (Figure 1). The crops selected for model calibration were potato (2013) and maize (2014). In this study only drip irrigation was used with two irrigation strategies either as regulated deficit irrigation (RDI) or partial root drying (PRD) strategy with fresh water (surface water, SW) and treated waste water (TWW). The latter was spiked with salts to increase its salinity to study the soil salinity distribution and its impact on growth, and yield. All the samples required for the model calibration and validation were taken over the crop growing seasons during each growing phase. The soil moisture and salinity were measured continuously by SMEC 300 sensors at two depths $25-35 \mathrm{~cm}$ and $55-65 \mathrm{~cm}$ depth.

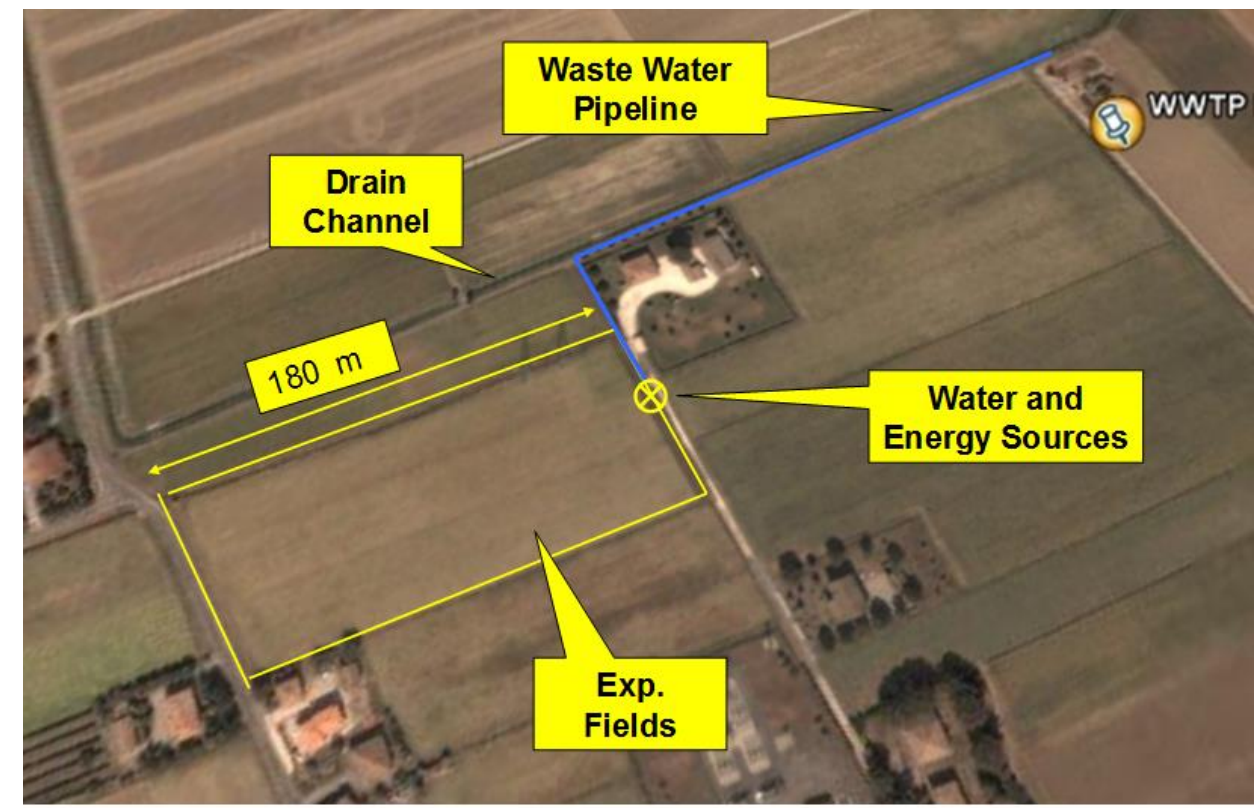

Figure 1. Experimental site at CER (Bologna, Italy)

All the required climatic variables data were collected on site from the available weather station. The planting and harvesting dates for potato were $22^{\text {nd }}$ of March 2013 and $24^{\text {th }}$ of July 2013, respectively; whereas maize sowing and harvesting dates were $26^{\text {th }}$ of March 2014 and $24^{\text {th }}$ of September 2014, respectively. Climate data required as input to the model consist of precipitation, maximum temperature and minimum temperature, the relative humidity, net and total radiation.

\subsection{Irrigation strategies and field measurements}

For the two crops drip irrigation system was applied as shown in the plot layout (Figure 2). The size of the harvest plot was $10 \mathrm{~m}^{2}$ while the size of each block was different but it's not useful for the simulation. As a matter of fact one can choose whatever area you want from $1 \mathrm{~m}^{2}$ to 1 hectare, it's just matter to correctly refer the measurements. The drip line has an emitter spacing 
of $0.3 \mathrm{~m}$ and a nominal flow of $0.8 \mathrm{l} / \mathrm{h} / \mathrm{emitter}$. The number of dripper within $1 \mathrm{~m}^{2}$ is same irrespectively to the irrigation strategy $\left(4.43 \mathrm{dripper} / \mathrm{m}^{2}\right)$. The sensors and the suction cups were placed in each plot to detect the soil moisture and the soil salinity. For the RDI irrigation strategy the drippers were placed next to the plant; whereas, for the PRD double lines were used, with drippers placed in the mid-point between two plants (Figure 3). The soil moisture and salinity sensors and suction cups installation is shown in Figure 3 for the potato crop.

In addition, dry matter and total leaf area which was required to calculate the Leaf Area Index (LAI), were obtained in situ at regular intervals. Total yield was measured during the harvesting period. Other plant parameters such as plant height, root depth, length of each growth stage and harvest index were also based on field measurements. The growth period for potato and maize crops were 122 and 186 days, respectively. The irrigation and fertigation was managed by means of the FertOrgaNic and Fertirrigere Maize DSS model, respectively for potato and maize, which are calibrated and validated for these crops in the area (Battilani, 2006a; Battilani et al, 2006b). In this study Naan Dan Jain drip system was applied for the irrigation. PRDirrigated plots were managed as for RDI plots, with a reduction of $25 \%$ of the calculated irrigation depth during the PRD-treatment period (Figure 4).

Results obtained during a former experimentation (SAFIR) were applied to manage PRD in potato and processing tomato. Maize PRD criteria was defined as:

a) Irrigation thresholds: In the early growth stage, from emergence to $80 \%$ of tuber $>2 \mathrm{~cm}$, potato is very sensitive to water and nutrient stresses (Figure 4). Furthermore, the variety utilised (Agata) have a marked proneness to reduce rapidly both growth and yield because of water and nitrogen stresses. Considering this constraint PRD management on that stage is similar to RDI. Therefore, a little increase in soil water tension is bearable so the irrigation threshold, from $80 \%$ of tubers $>2 \mathrm{~cm}$ to $50 \%$ of tuber $>6 \mathrm{~cm}$, is set at $-10 \%$ respect to RDI $\left(0.70 \mathrm{AW}_{\mathrm{FC}}\right.$ vs $0.8 \mathrm{AW}_{\mathrm{FC}} ;-90 \mathrm{kPa}$ vs $\left.-70 \mathrm{kPa}\right)$. At this stage irrigation frequency or volume were increased because of high temperature, strong windy days or early dryness in order to avoid yield losses. In the late development stages, from $50 \%$ of tubers $>6 \mathrm{~cm}$ to $50 \%$ of leaf senescence or harvest PRD were irrigated when $0.50 \mathrm{AW}_{\mathrm{FC}}$ remain or at a tension of about $185 \mathrm{kPa}(\mathrm{RDI}=0.7 \mathrm{AW}$ FC and $-90 \mathrm{kPa})$. 


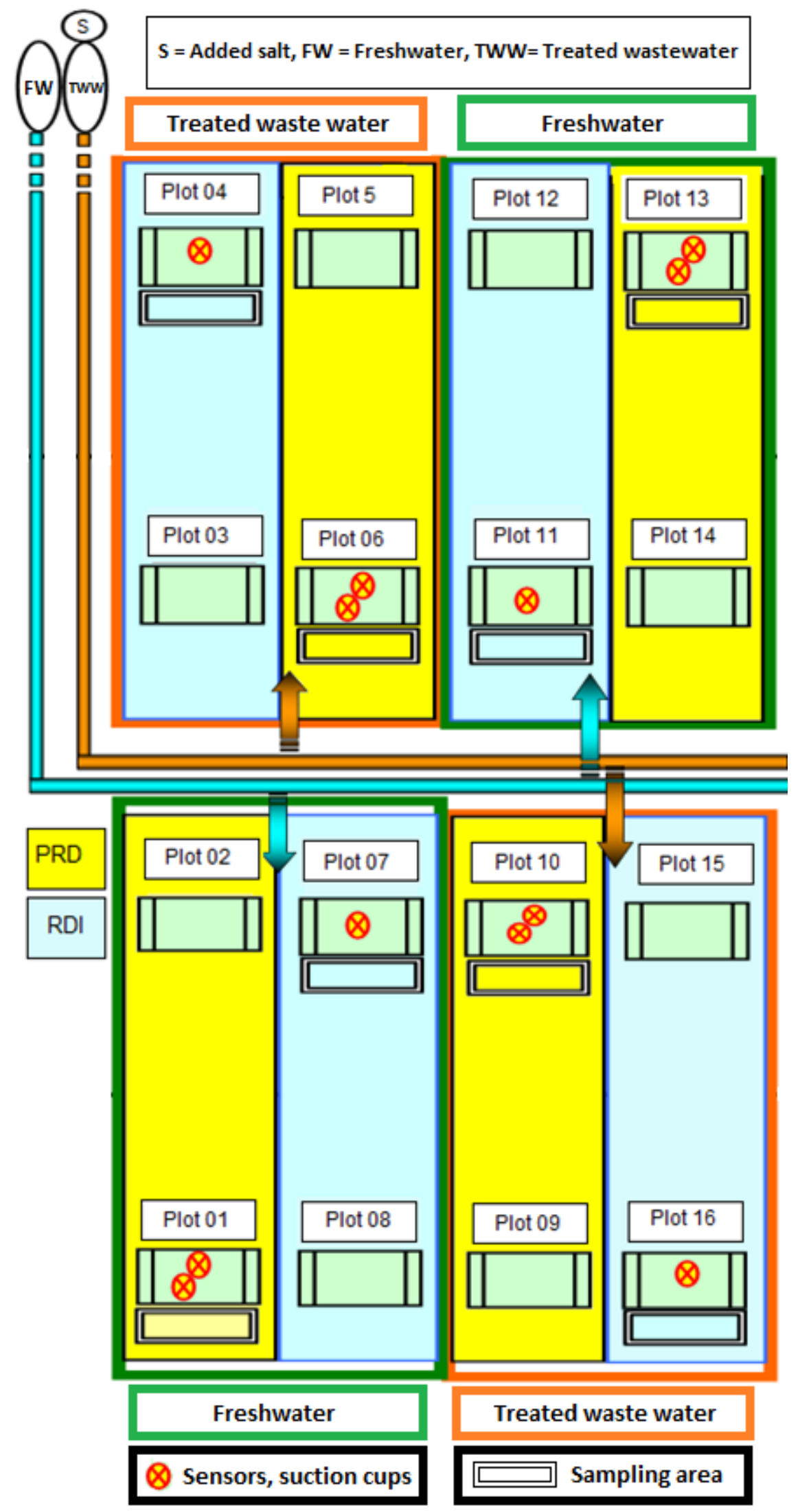

Figure 2. Plot layout of the irrigation treatments 


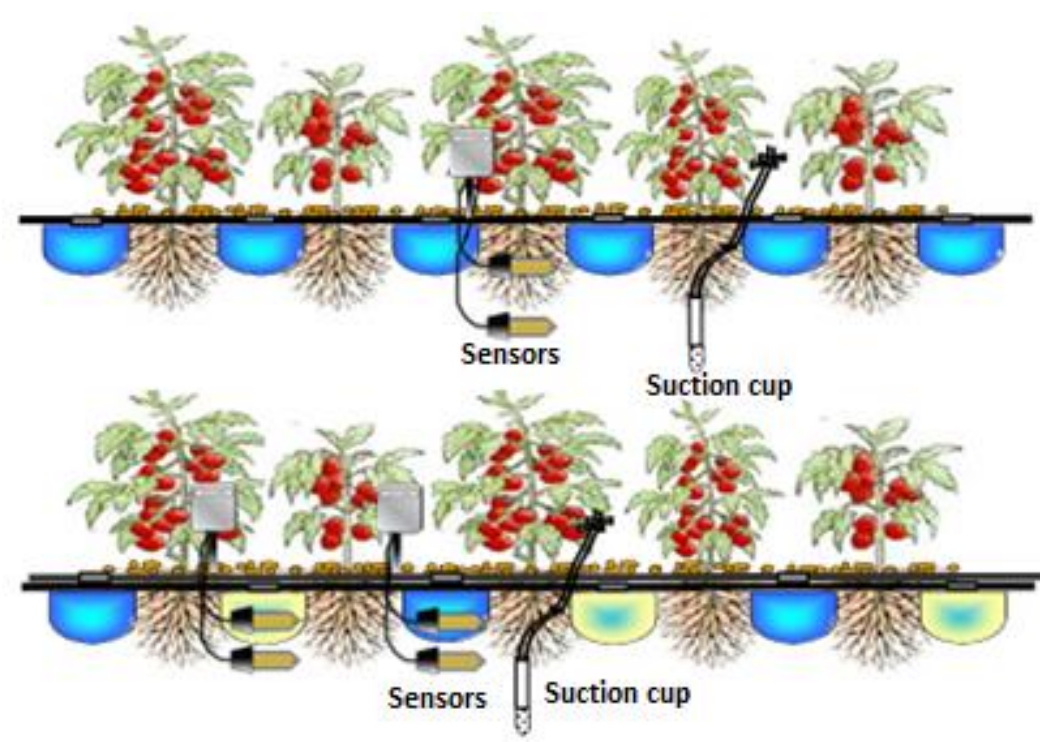

Figure 3. Sensors and suction cups installation scheme. In the upper part is the RDI treatment, in the bottom part is the PRD plots.
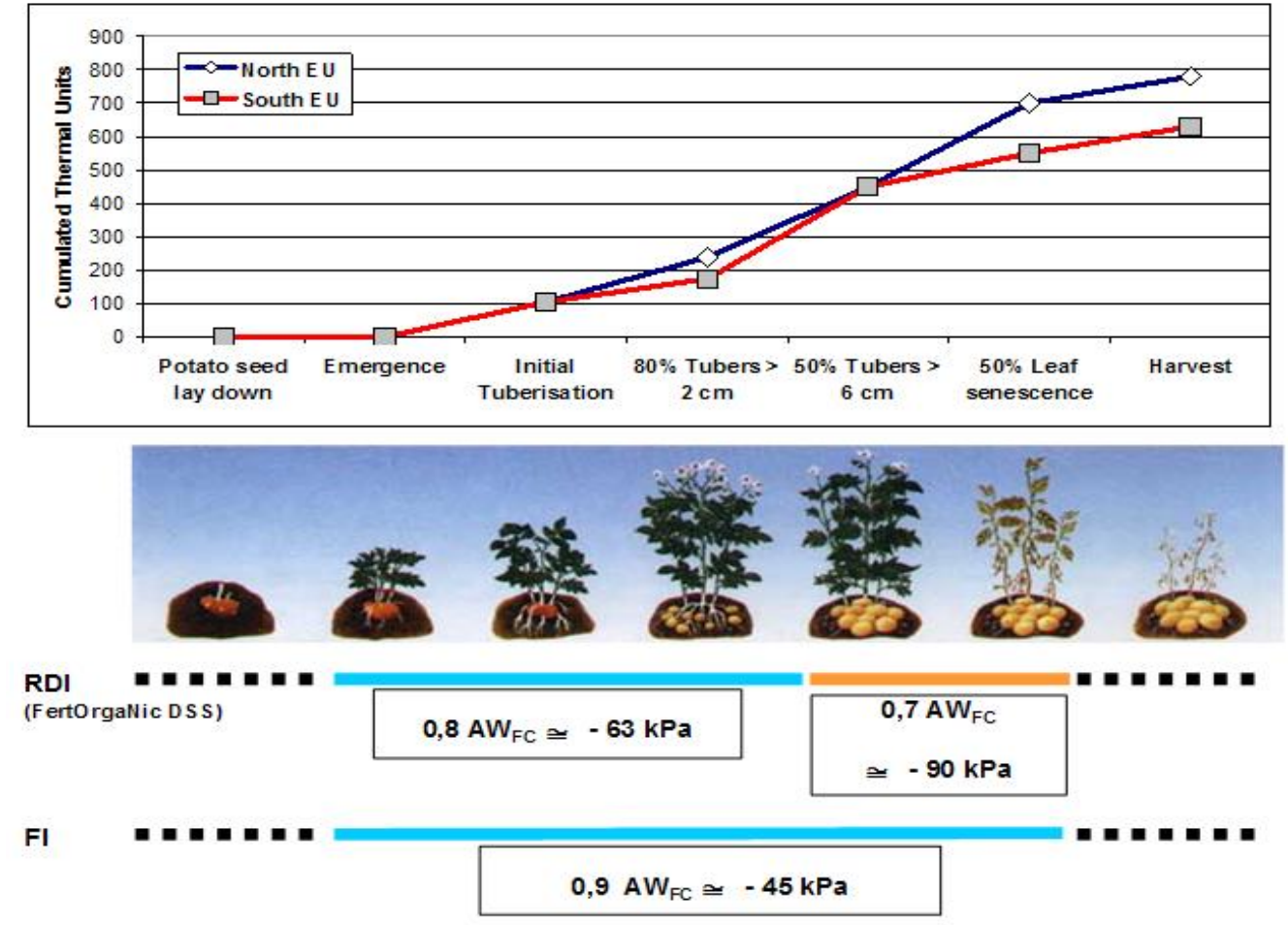

PRD

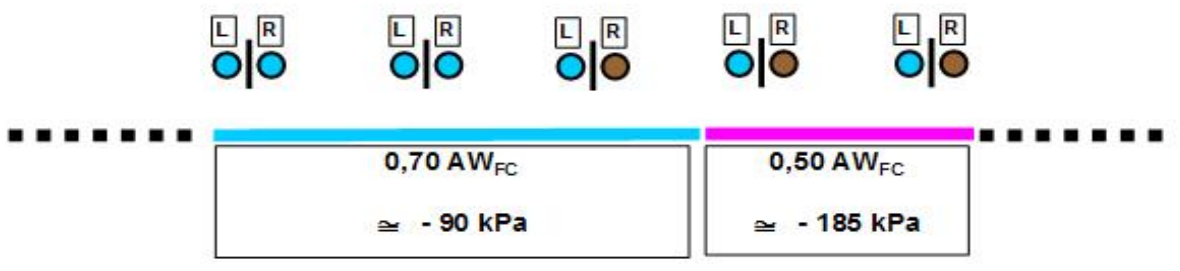

Figure 4. Crop growth stages and irrigation treatment over time. 
b) Side Shifting: PRD irrigation was shifted every time approximately $>30 \mathrm{~mm}$ of irrigation water has been supplied in the RDI irrigated treatment. The dynamic PRD management was carried following: from emergence to $80 \%$ of tuber $>2 \mathrm{~cm}$ no side shifting is forecast; shifting only started when $80 \%$ of tubers reach a size of about $2 \mathrm{~cm}$ (equatorial diameter).

c) PRD start up: PRD management started in potato when the $75 \%$ of maximum vegetative growth reached as shown in figure 4 (approximately at first flowers or initial tuber initiation $25 \%$ of tubers $>2 \mathrm{~cm}-)$.

\subsection{Model calibration}

During the calibration, fine tuning of the relevant SALTMED model parameters was carried out against the observed data for the soil moisture, soil salinity, crop yield and total dry matter. In this analysis, RDI irrigation with freshwater was selected for the calibration process. For the soil moisture calibration, different soil parameters such as soil hydraulic properties including bubbling pressure, saturated hydraulic conductivity, saturated soil water content and pore distribution index, "lambda" were fine-tuned until close matching between the simulated and observed values was achieved. In addition to the soil parameters, other crop parameters such as the crop coefficient, $\mathrm{Kc}$, that is used to predict crop evapotranspiration $\left(\mathrm{ET}_{\mathrm{c}}\right)$ and basal crop coefficient, $\mathrm{K}_{\mathrm{cb}}$, that represents the crop transpiration part of the Kc were also slightly tuned to find the best fit of the soil moisture against the observed soil moisture for each layer. After achieving a good fit for the soil moisture, only fine tuning was needed for the crop yield and total dry matter. The key parameters that were required to fine tune for the crop yield were photosynthetic efficiency, crop coefficients $\mathrm{Kc}$ and $\mathrm{Kcb}, \pi_{50}$ and fraction cover, $\mathrm{F}_{\mathrm{c}}$. Where, $\pi_{50}$ is the time dependent value of osmotic pressure at which maximum potential root water uptake is reduced by $50 \%$ (Ragab, 2002) and Fc is the fraction cover of the canopy above the soil surface.

\subsection{Model validation}

The simulated soil moisture, soil salinity, total dry matter and total crop yield were compared with the observed data obtained from the field experiments after calibrating the model. The RDI irrigation strategy using fresh water was calibrated first then validated against all irrigation treatments including treated waste water for RDI. Validation was also carried out for PRD 
strategy for surface water and treated waste water. During the validation stage, the model was run with all calibrated soil and crop parameters unchanged.

\subsection{Goodness of fit}

For the model calibration and validation statistical measures, $\mathrm{R}^{2}$ coefficient and percentage error were used. The first index was $\mathrm{R}^{2}$ coefficient:

$$
R^{2}=\left(\left\{\frac{1}{N} \frac{\sum\left[\left(y_{0}-\bar{y}_{o}\right)\right]\left(\bar{y}_{s}-\bar{y}_{o}\right)}{\sigma y_{0}-\sigma y_{s}}\right\}\right)
$$

Where $\mathrm{y}_{\mathrm{s}}$ is the simulated value, $\mathrm{y}_{\mathrm{o}}$ is the measured value, $\mathrm{N}$ is the total number of observations, $\bar{y}_{\mathrm{o}}$ is the average measured value, $\bar{y}_{\mathrm{s}}$ is the average simulated value, $\sigma y_{0}$ is the observed data standard deviation and $\sigma y_{s}$ is the simulated data standard deviation. The values of this index can range from 1 to 0 , with one indicating perfect fit. The other statistical measure which was used to find the fitness of the model was percentage error, the value of this index can range from $0 \%$ to $100 \%$, and with $0 \%$ indicating perfect fit of the model.

\section{Results and Discussion}

\subsection{Soil moisture}

Initially the soil moisture was calibrated with RDI with fresh water and validated against all the other treatments. The model has shown a good fit for both layers $(25-35$ and $55-65 \mathrm{~cm}$ depth) of the simulated soil moisture when compared with the observed soil moisture (Figures 5-7). The simulated soil moisture content was slightly lower in the middle period and slightly higher in the late period in comparison to the observed soil moisture. This is mainly due to the high water uptake by the plant during the peak of the growth season. Overall the model showed a good fit against the observed data both during the calibration and validation stages. These result are consistent with those obtained by Pulvento et al., (2013, Pulvento et al., (2015a), Hirich et al. (2012), Silva et al. (2013) Ragab et al. (2015), Fghire et al. (2015) and Rameshwaren et al. (2015). 

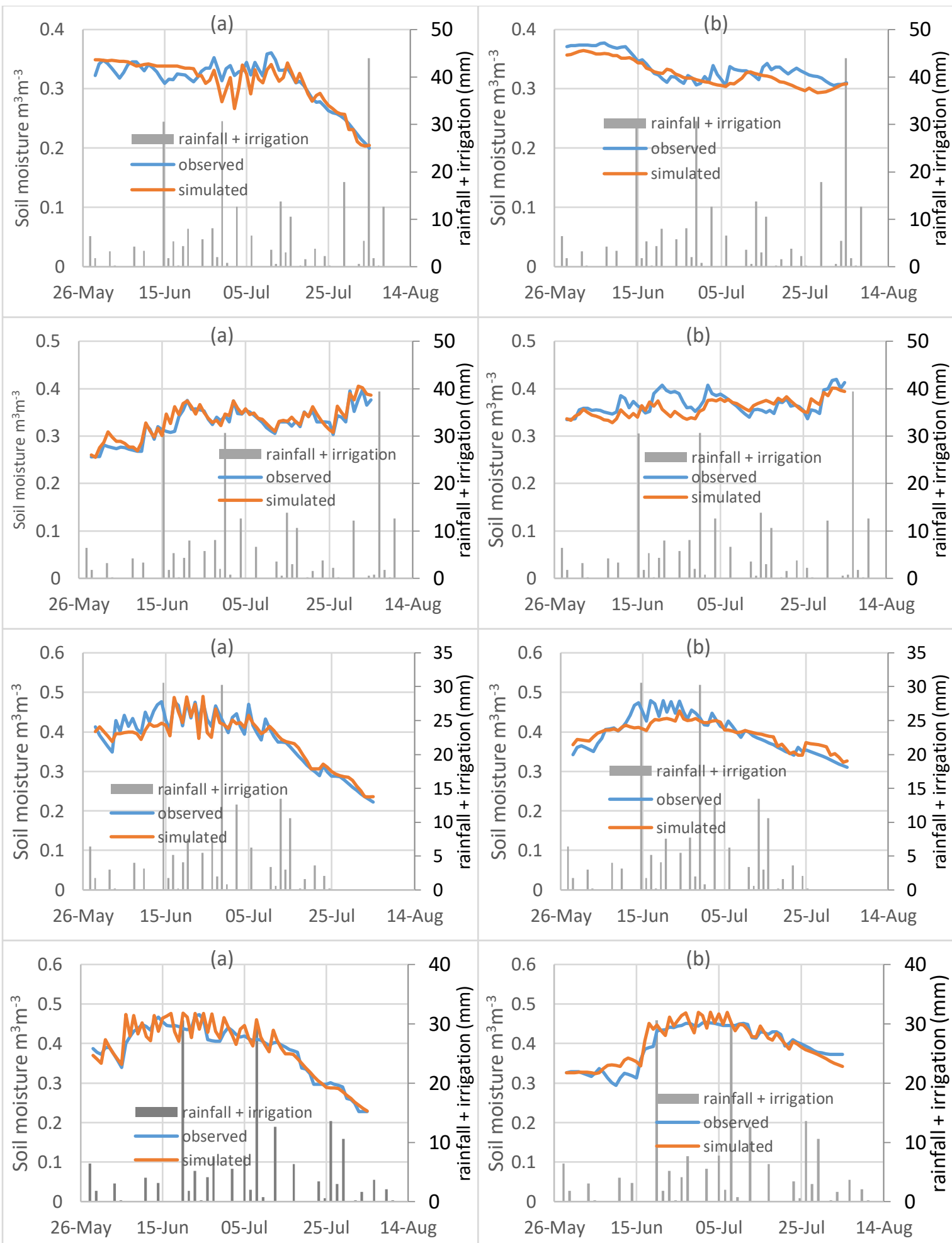

Figure 5. Observed and simulated soil moisture for potato 2013 in Bologna, Italy where figure (a) refers to the layer-1 and (b) refers to the second layer for all irrigation strategies (RDI Surface fresh water, SW, RDI, Treated waste Water, TWW, PRD SW and PRD TWW) from the top to bottom. The model was calibrated for the RDI SW (top figures $\underline{\mathbf{a} \& \mathbf{b}}$ ) and validated against the other irrigation time series. 


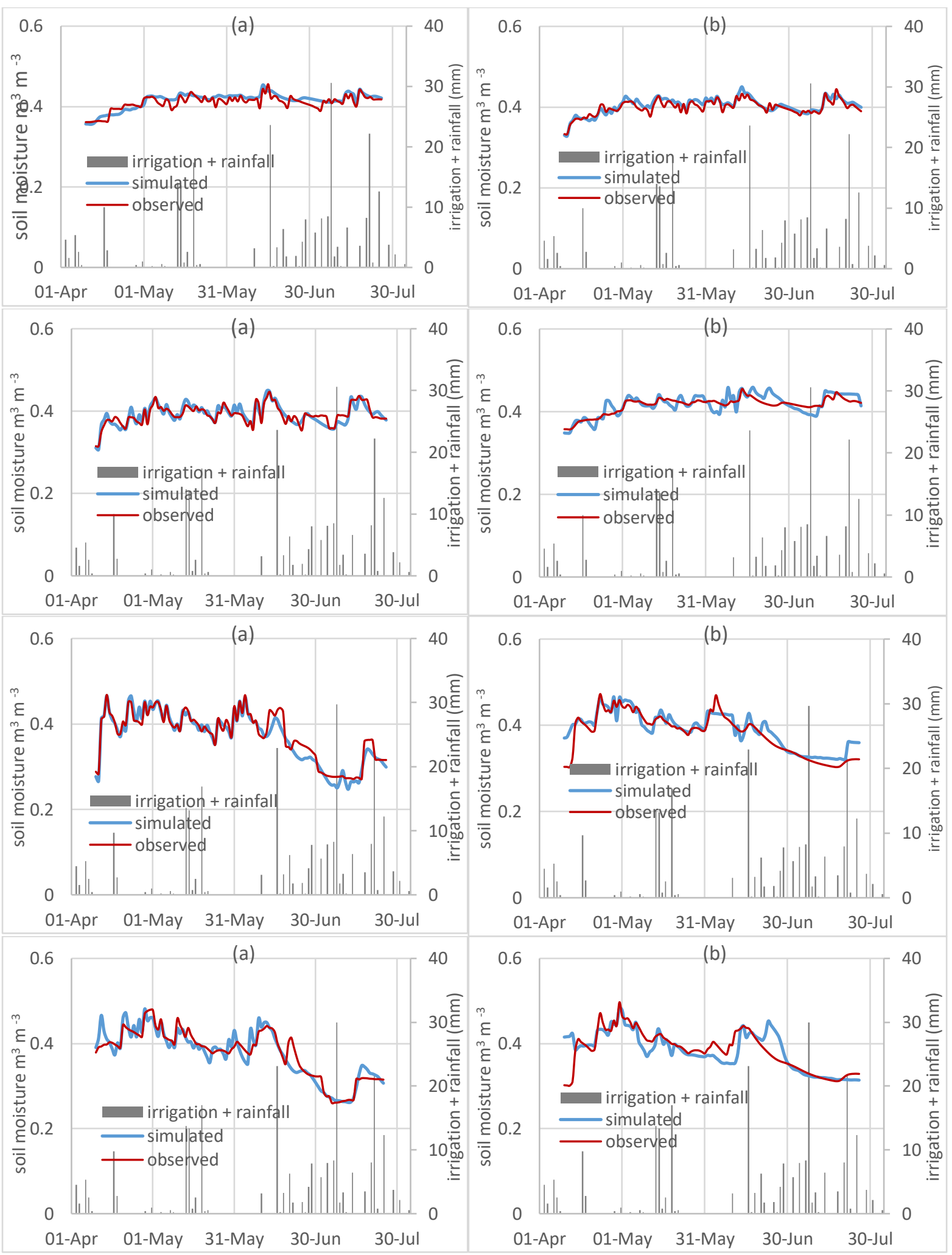

Figure 6. Observed and simulated soil moisture for maize 2014 in Bologna, Italy where figure (a) refers to the layer-1 and (b) refers to the layer-2 for all irrigation strategies (RDI surface fresh water, SW, RDI, Treated waste Water, TWW, PRD SW and PRD TWW) from the top to bottom. The model was calibrated for the RDI SW (top figures $\underline{\mathbf{a} \& \mathbf{b}}$ ) and validated against the other irrigation time series. 

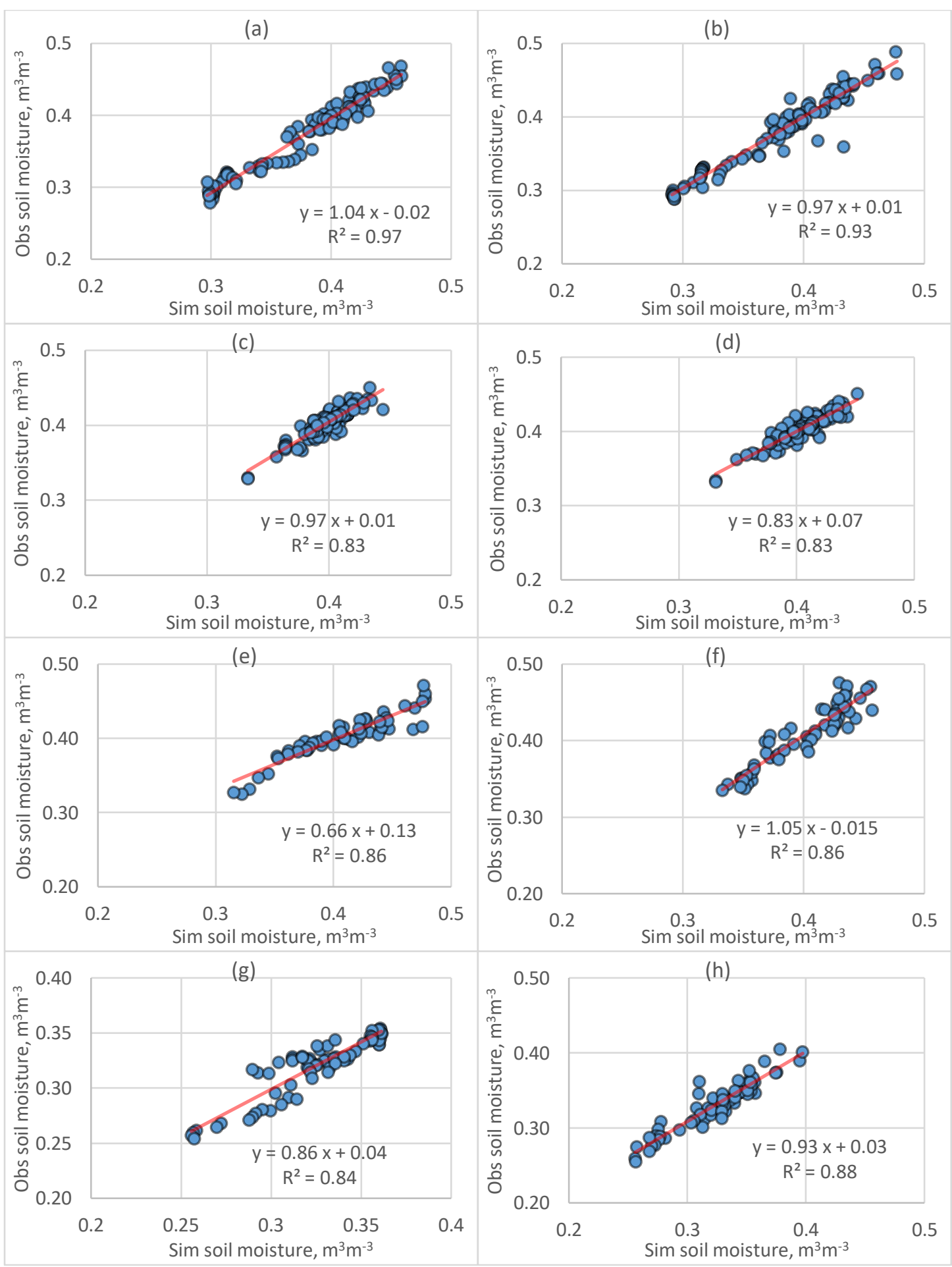

Figure 7. Observed and simulated soil moisture for all types of treatments, PRD with SW (a \& e), PRD with TWW (b \& f), RDI with SW (c \& g) and RDI with TWW (d \& h) for potato 2013 and maize 2014 for both layers

The model showed slightly higher values for the $\mathrm{R}^{2}$ for the top layer in comparison to the bottom layer under all treatments (Figure $7 \&$ Table 1). In general the treatments with surface fresh water (both RDI \& PRD) showed a better fit than those with treated waste water more particularly for the top layer. This could be due to different response of the soil layers to the irrigation and rainy spells. These findings are consistent with other studies including (Pulvento 
et al., 2013,Silva et al., 2013, Hirich et al., 2012) who observed that, for the top layer, SALTMED proved its high sensitivity to simulate the soil moisture changes due to irrigation and rainfall events. Overall the simulated and the observed soil moistures for all treatments showed strong correlation between the observed the simulated soil moisture (Figure 8).

Table 1. Soil moisture during the model calibration and validation.

\begin{tabular}{|c|c|c|c|c|c|c|c|}
\hline \multirow{2}{*}{$\begin{array}{c}\text { Irrigation } \\
\text { system }\end{array}$} & Year & \multicolumn{2}{|c|}{ Layer-1 } & \multicolumn{2}{c|}{ Layer-2 } & \multicolumn{2}{c|}{ Average 2-layers } \\
\cline { 3 - 8 } & & $\%$ error & $\mathrm{R}^{2}$ & \% error & $\mathrm{R}^{2}$ & \% error & $\mathrm{R}^{2}$ \\
\hline \multirow{3}{*}{ RDI-SW $^{*}$} & 2013 & 1.76 & 0.84 & 1.53 & 0.82 & 1.25 & 0.92 \\
\cline { 2 - 8 } & 2014 & 1.28 & 0.88 & 1.488 & 0.87 & 1.07 & 0.91 \\
\hline & 2013 & 1.18 & 0.89 & 1.21 & 0.90 & 1.29 & 0.92 \\
\cline { 2 - 8 } PRD-SW & 2014 & 1.77 & 0.96 & 2.164 & 0.91 & 1.59 & 0.98 \\
\hline \multirow{3}{*}{ PRD-TWW } & 2013 & 2.33 & 0.88 & 2.04 & 0.93 & 1.62 & 0.93 \\
\cline { 2 - 8 } & 2014 & 2.57 & 0.90 & 3.159 & 0.88 & 1.75 & 0.93 \\
\hline \multirow{3}{*}{ RDI-TWW } & 2013 & 2.76 & 0.86 & 2.65 & 0.85 & 2.10 & 1.87 \\
\cline { 2 - 8 } & 2014 & 1.17 & 0.87 & 1.464 & 0.83 & 0.90 & 0.91 \\
\hline
\end{tabular}

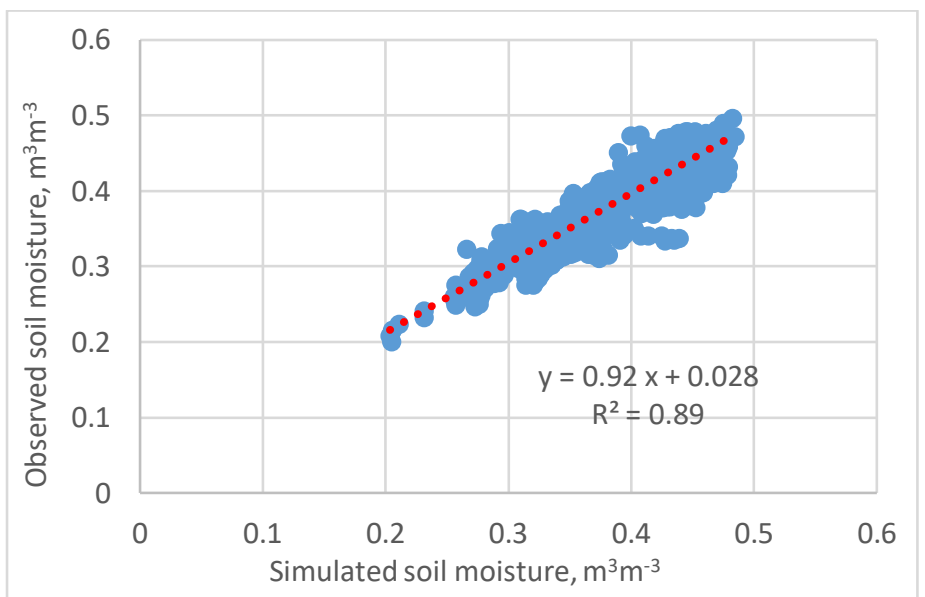

Figure 8. The correlation between the observed and simulated soil moisture for all types of treatments

\subsection{Soil salinity}

The soil salinity was also simulated for all irrigation strategies RDI and PRD for both fresh water and treated-waste water. In this study the simulated soil salinity was compared with the observed soil salinity measured in the field with the sensors (both at depth 55-65 cm). The simulated results for both calibration and validation were close to the observed soil salinity (Figure 9). At the early start, the simulated soil salinity was slightly lower than the observed soil salinity more particularly for the PRD treatment with the treated wastewater. The observed and simulated soil salinity was lower for the treatments with the freshwater (Figures 10 a\&e and $c \& g$ ) and higher for those which were irrigated with the treated waste water (Figures 10 b\&f \& d\&h). 


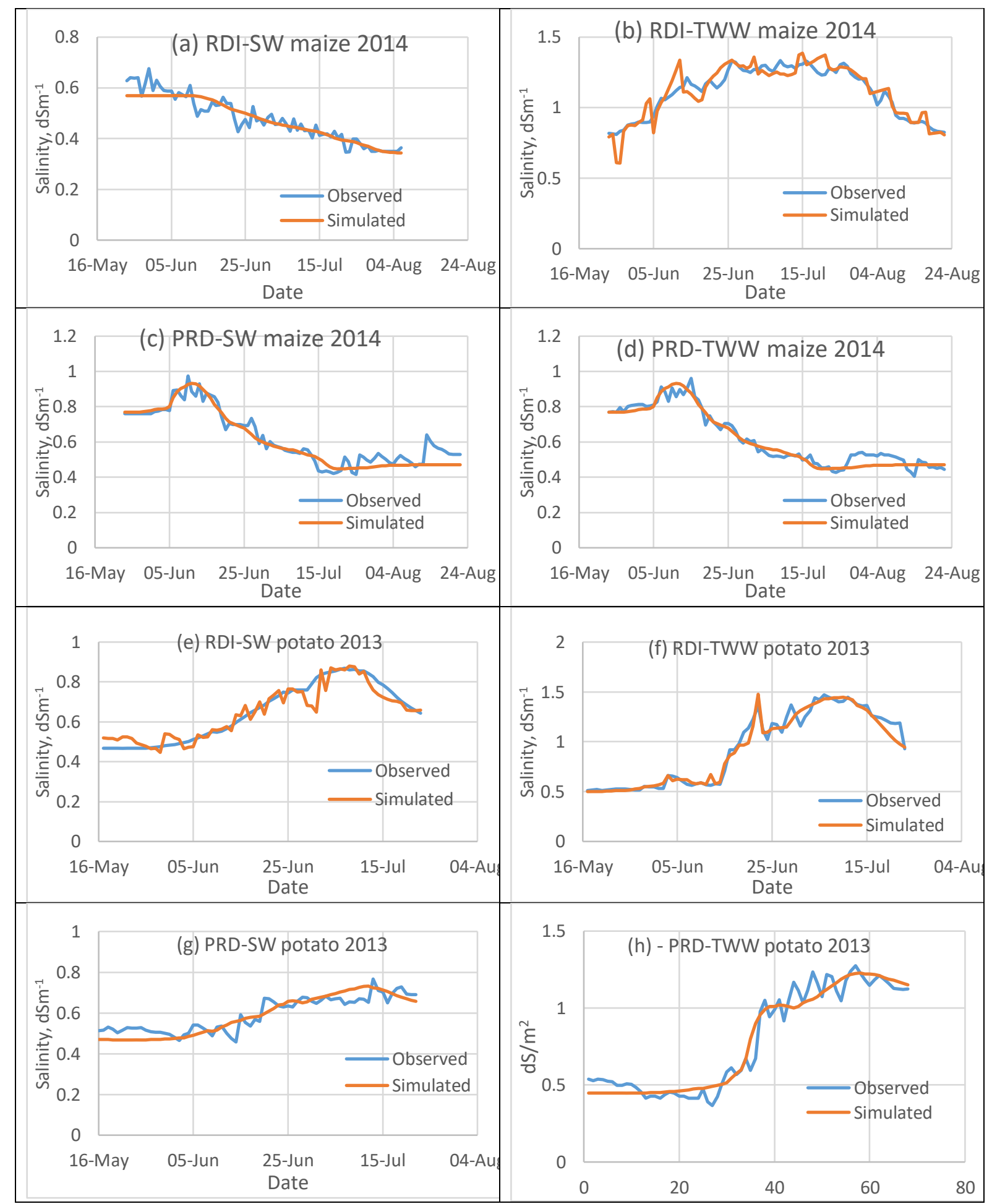

Figure 9. The observed and simulated soil salinity for the both RDI-SW (a \& e), RDI-TWW (b \& f), PRD-SW (c \& g) and PRD-TWW (d \& h) for the both maize (a-d) and potato (e-h) crops. 

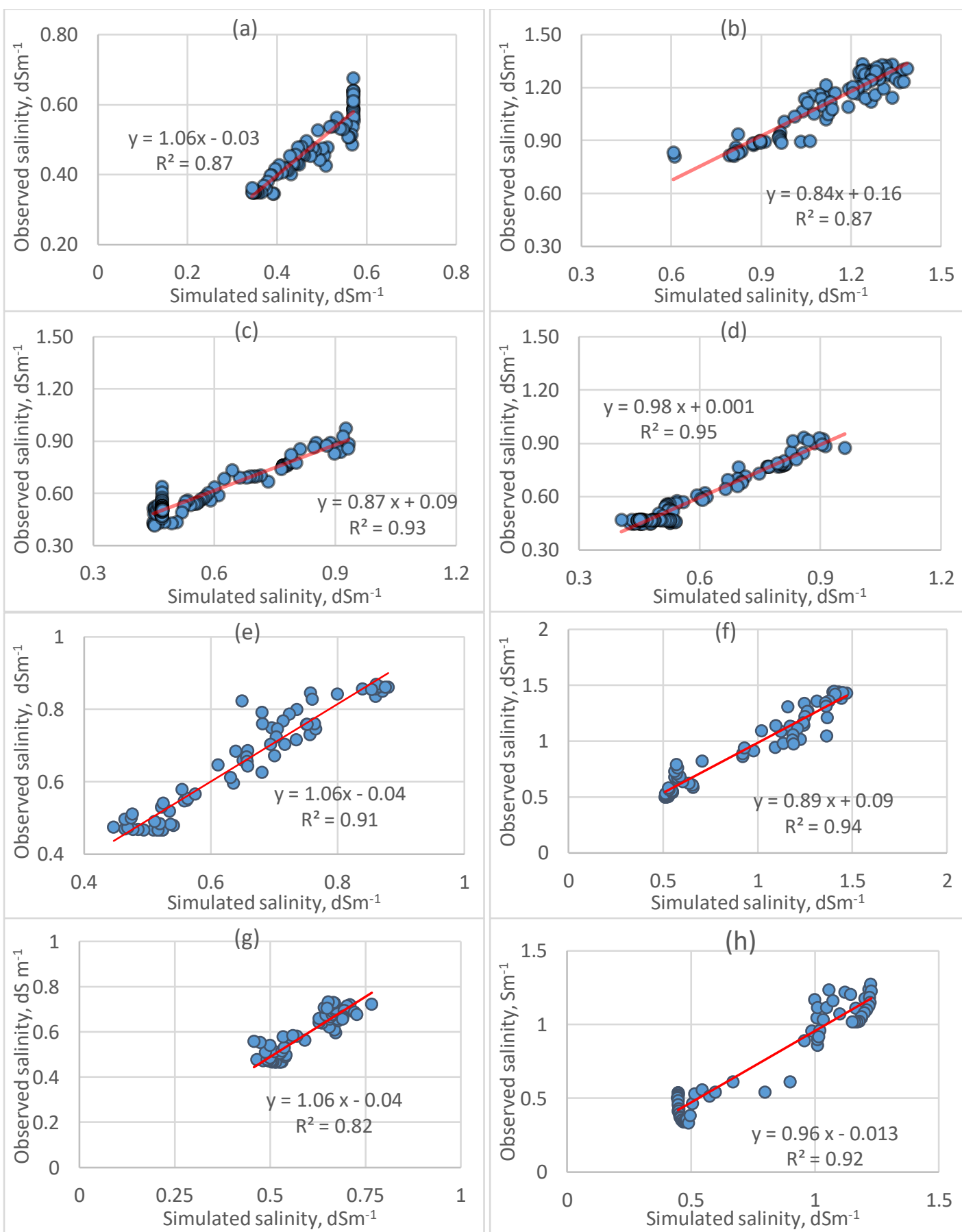

Figure 10. Observed and simulated salinity for RDI SW, RDI TWW, PRD SW and PRD TWW treatments for both potato (a-d) and maize crops (e-h).

Overall the observed and simulated soil salinity values are showing good fit for all treatments. An overall strong correlation was obtained between the observed and simulated soil salinities (Figure 11). 


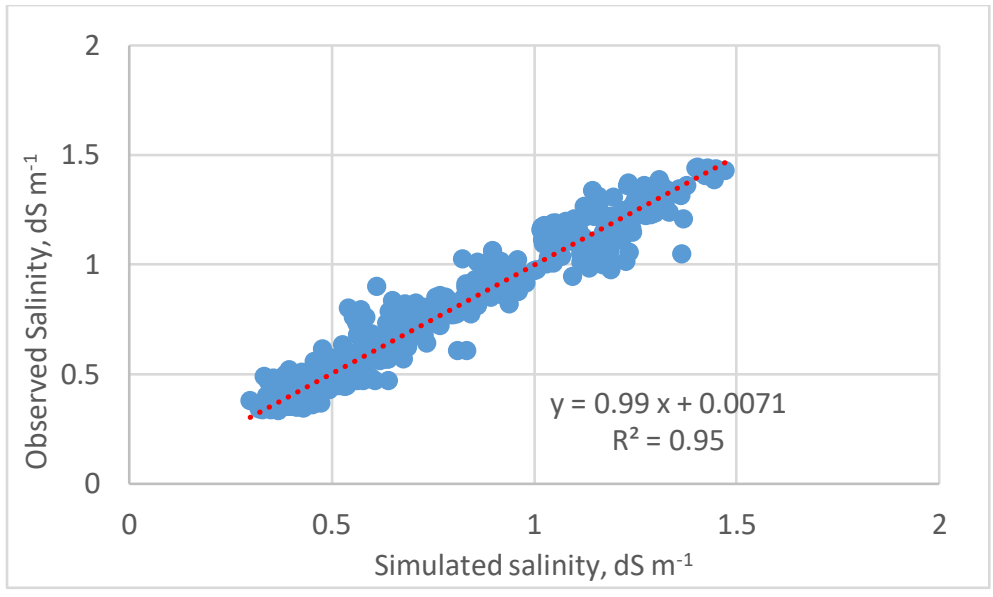

Figure 11. The relationship between observed and simulated salinity over a depth of $(25-35 \mathrm{~cm})$ and $(55 \mathrm{~cm}-65 \mathrm{~cm})$ for all potato and maize treatments for the years 2013 and 2014.

\subsection{Dry matter and crop yield}

Figures 12 and 13 show the observed and simulated total yield for the potato and maize crops under different irrigation strategies. The results show almost similar amount of yield under different irrigation strategies, although there was a difference in total irrigation (rainfall + actual irrigation). For example, the total irrigation for the RDI was higher by, $8 \%$, compared to PRD when using freshwater, whereas the total yield was slightly higher for the PRD strategy, by $4 \%$, when irrigated with fresh water for the potato crop (Figure 12). Whereas for the other treatments, simulated and the observed crop yield difference was minimal for the potato crop. On contrary to the potato crop, both RDI treatments showed slightly higher crop yield than PRD treatment for the maize crop. Irrigation water amount used for TWW was slightly higher in both RDI and PRD when using treated waste water as this treatment requires application of extra water for leaching of salts from the root zone to prevent excessive accumulation as shown in Table 2. Overall, almost similar crop yields were obtained for both crops under all irrigation strategies, although the crop yield with treated waste water was slightly lower, except RDI with treated waste water for the maize which showed slightly higher crop yield (Figures 12-13). 


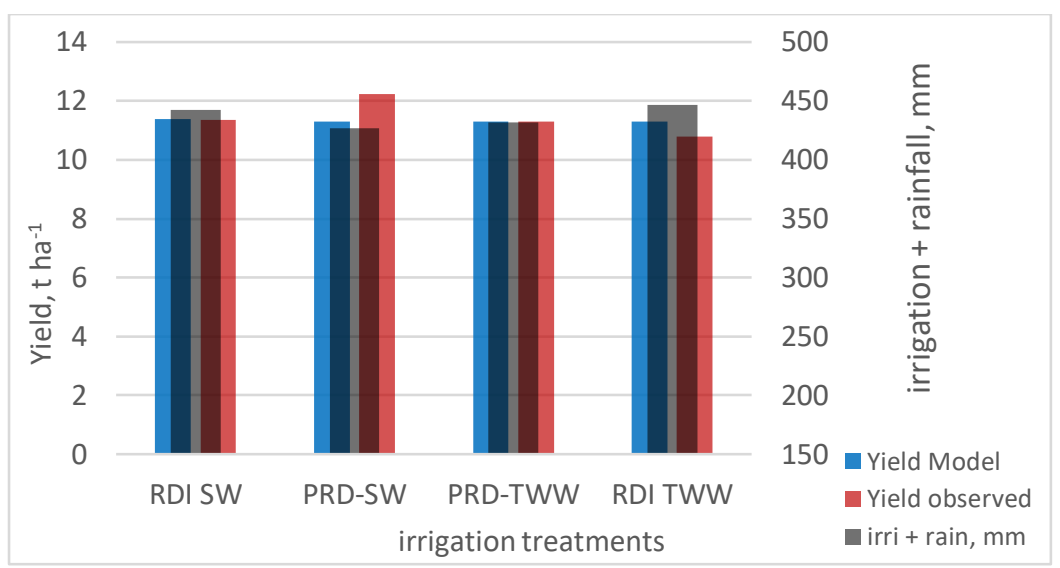

Figure 12. Observed and simulated potato yield and water supply under different irrigation treatments in Bologna, Italy for the year 2013.

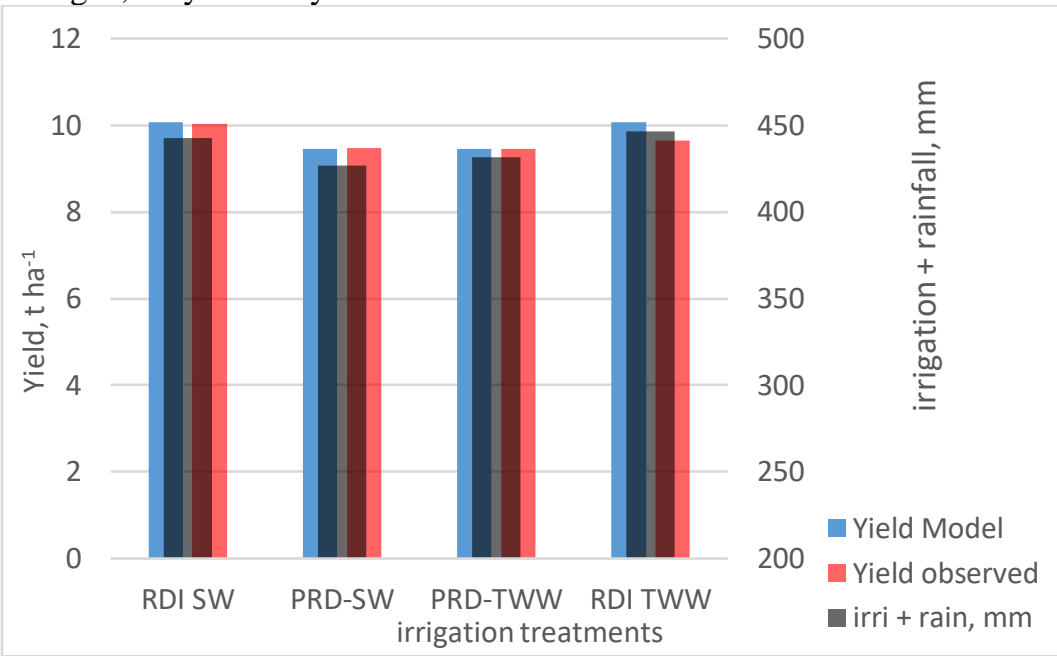

Figure 13. Observed and simulated maize total yield and water supply under different irrigation treatments in Italy for the year 2014 .

The correlation analysis between the total dry matter observed and the simulated dry matter shows that the model was able to simulate the total dry matter with $\mathrm{R}^{2}$ of 0.98 for all treatments for both potato and maize crops (Figure 14). The model also showed a good fit for the total yield over the study periods for the potato and maize crops, where $\mathrm{R}^{2}$ of 0.97 and 0.94 , respectively, was observed for both crops against the simulated yield (Figures 15 \& 16). 


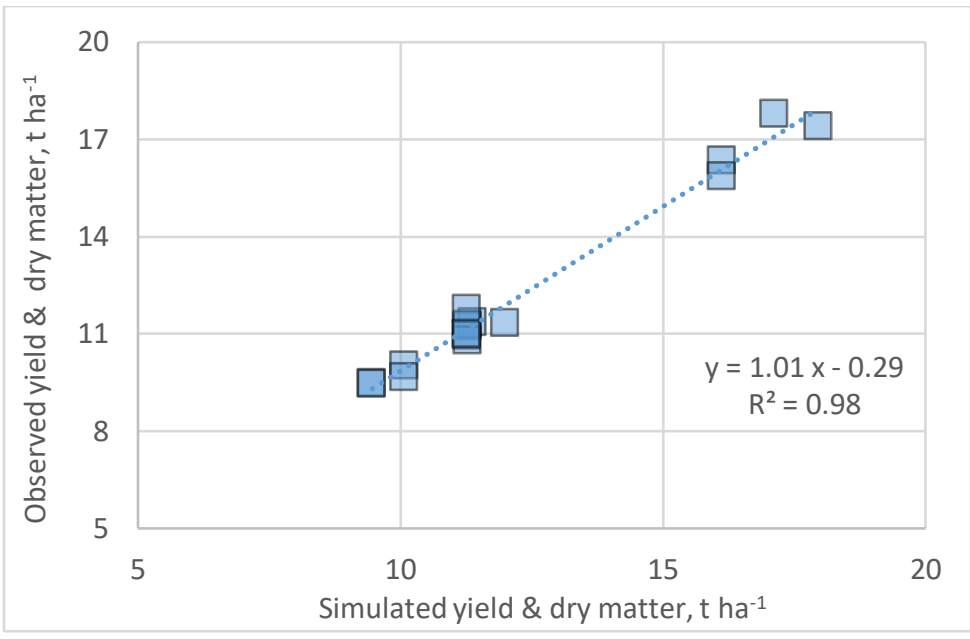

Figure 14. The overall observed and simulated dry matter and yield for both maize and potato crops for the years 2013 and 2014 under different irrigation treatments in Bologna, Italy.

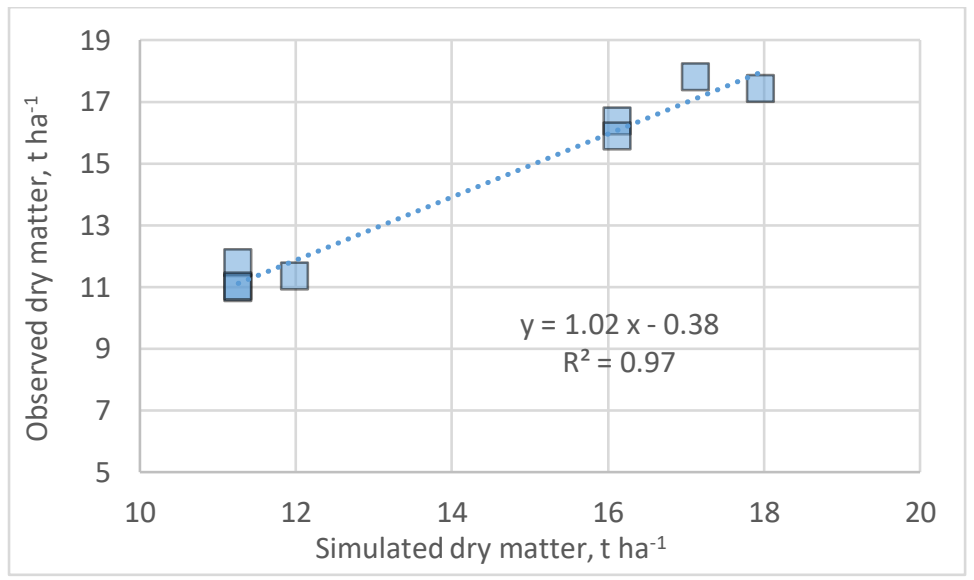

Figure 15. Observed and simulated maize and potato total dry matter for the years 2013 and 2014 under different irrigation treatments in Bologna, Italy.

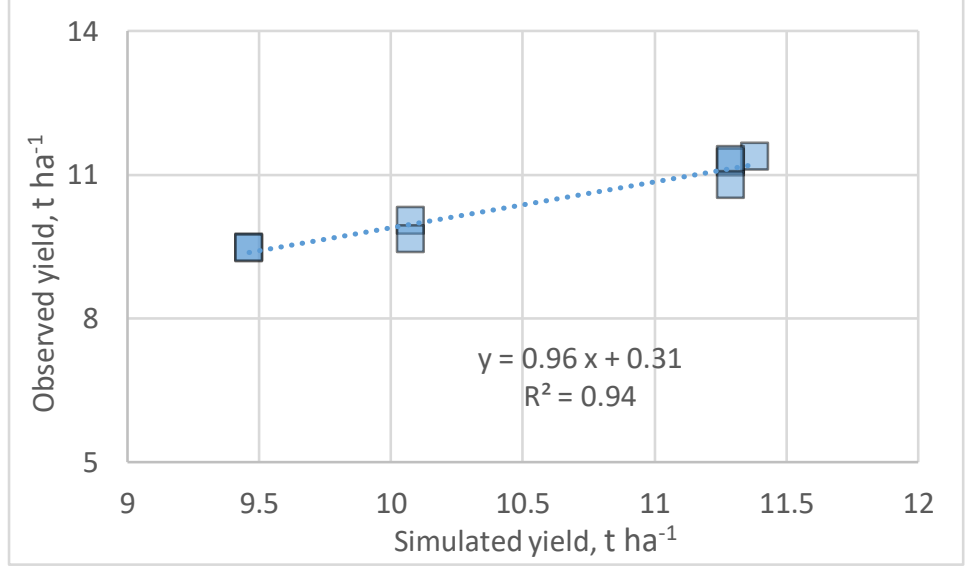

Figure 16. Observed and simulated maize and potato total yield for the years 2013 and 2014 under different irrigation treatments in Bologna, Italy.

The time series of the intermediate observed and simulated dry matter under different irrigation treatments for the both crops are shown in Figure 17. The observed and the simulated crop dry matters are very close to each other at the initial stage but in the middle stage, the observed dry 
matter is much closer to the simulated dry matter except for the RDI when using treated waste water. For maize crop, intermediate observed and the simulated dry matter have shown a good fit over the entire growth period. Overall, both crops showed a close agreement between the simulated and the observed dry matter during the intermediate growth stages for both crops, i.e. total dry matter for the potato showed $R^{2}$ of 0.92 (Figure 18) and $R^{2}$ of 0.95 for the maize for all treatments (Figure 19). The simulated results for both crops also showed a good correlation of intermediate total dry matter and the overall $\mathrm{R}^{2}$ for the potato and maize crop was 0.96 (Figure 20).

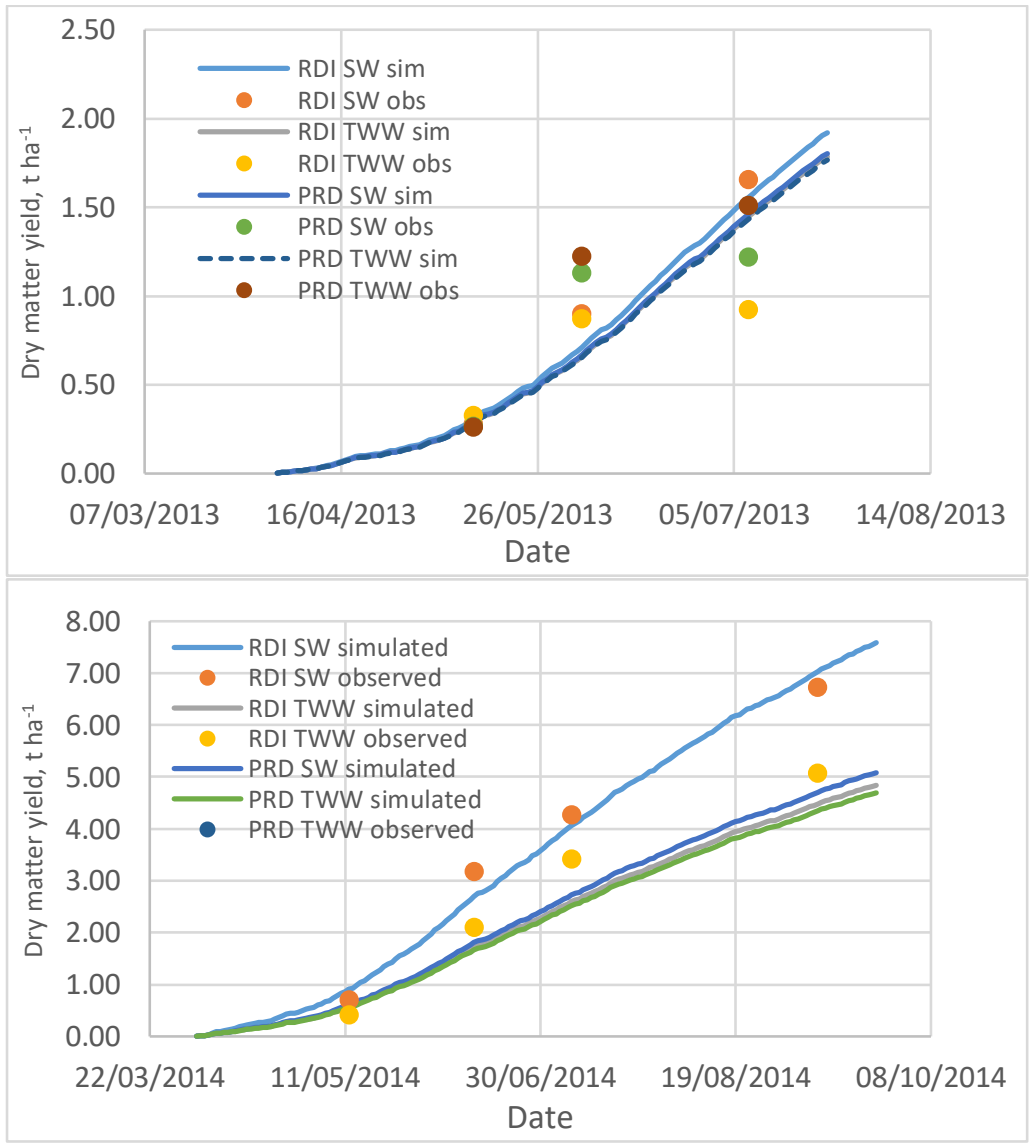

Figure 17. Intermediate observed and simulated potato (top) and maize (bottom) dry matter under different irrigation treatments in Italy for the years 2013 and 2014. 


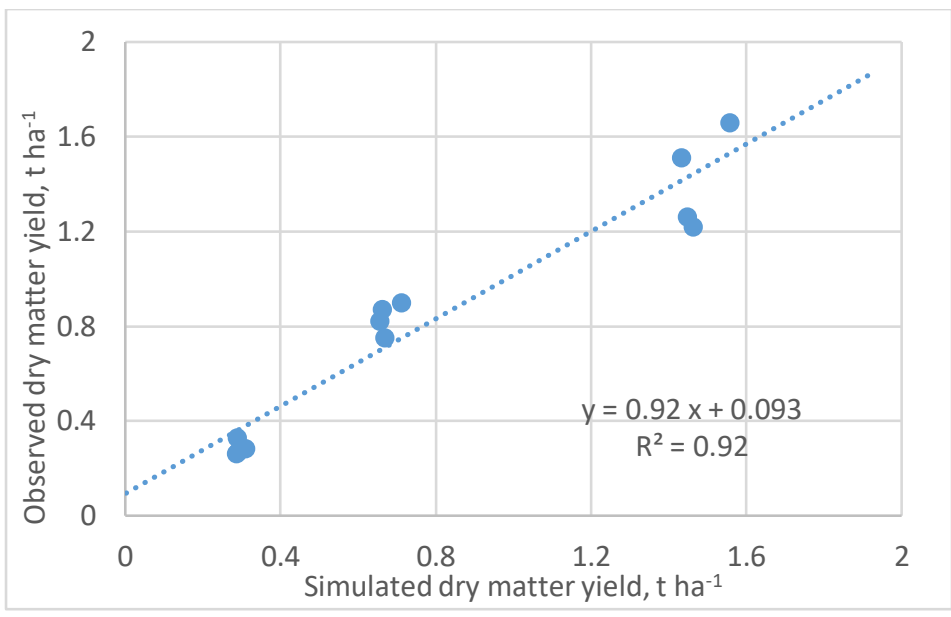

Figure 18. Intermediate observed and simulated potato dry matter under different irrigation treatments in Italy for the year 2013 .

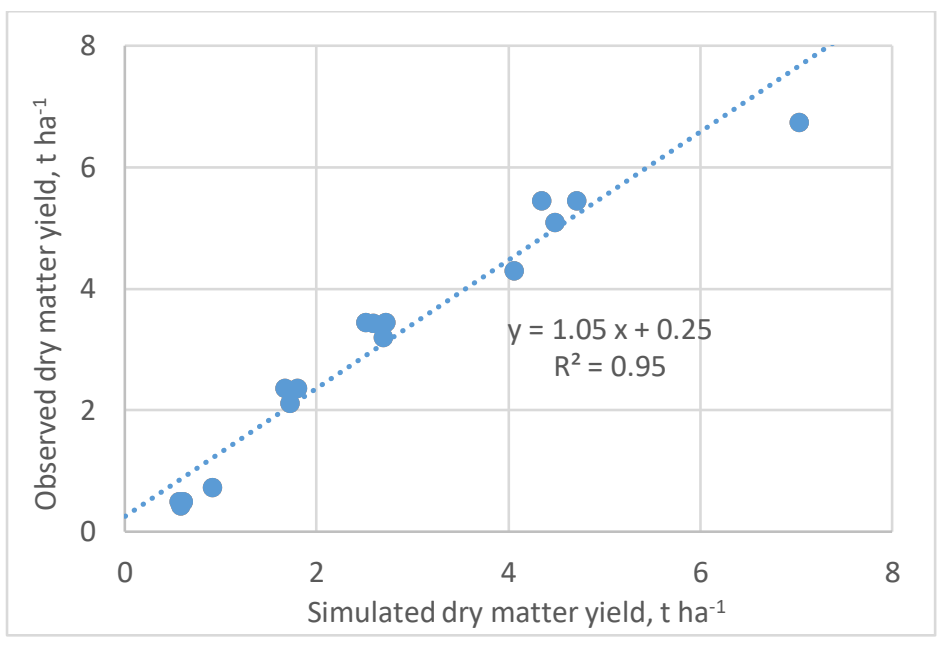

Figure 19. Intermediate observed and simulated maize dry matter under different irrigation treatments in Italy for the year 2014 observed well before the harvesting period.

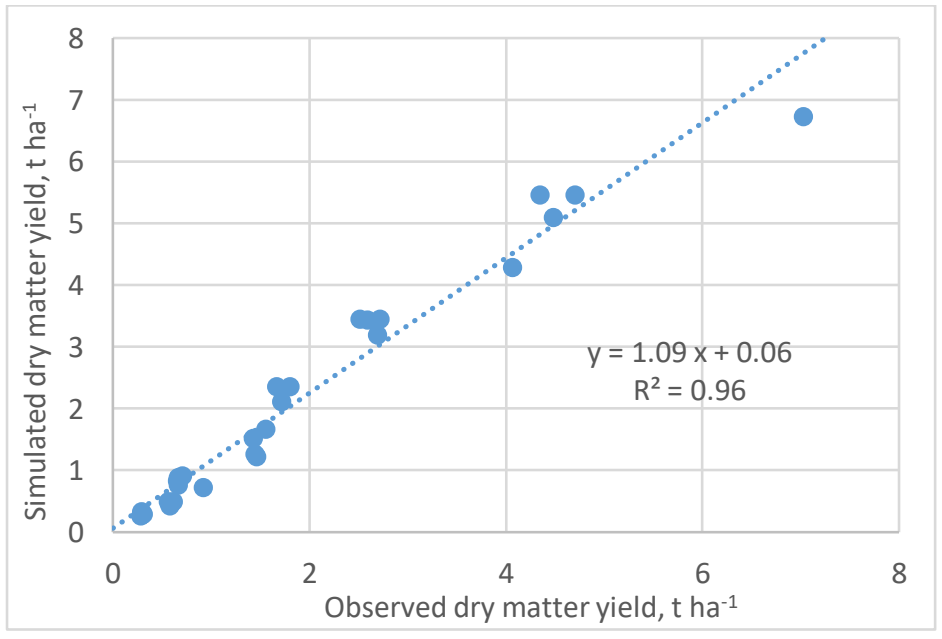

Figure 20. Intermediate observed and simulated intermediate dry matter under different irrigation treatments for both maize and potato crops for the years 2013 and 2014 observed well before the harvesting period. 


\subsection{Water productivity}

The water productivity was calculated as amount of dry matter and yield produced in $\mathrm{kg}$ per cubic meter of water needed including rainfall and irrigation. These results show that the water productivity was slightly high in PRD for both potato and maize crops during the years 2013 and 2014 (Figures $21 \& 22$ ). The rainfall amount remained almost the same for both years (Tables 2 and 3), however the water needed for irrigation was 15 to $17 \%$ lower for PRD than for RDI strategy.

For fresh water, the water productivity for potato yield was $2.27 \mathrm{~kg} \mathrm{~m}^{-3}$ under PRD and 2.26 $\mathrm{kg} \mathrm{m}^{-3}$ under RDI and for treated waste water, it was $2.24 \mathrm{~kg} \mathrm{~m}^{-3}$ for PRD and $2.16 \mathrm{~kg} \mathrm{~m}^{-3}$ for RDI. For maize, under fresh water treatment, the water productivity was $3.56 \mathrm{~kg} \mathrm{~m}^{-3}$ for PRD and $3.15 \mathrm{~kg} \mathrm{~m}^{-3}$ for RDI while under treated waste water, the water productivity was $3.27 \mathrm{~kg}$ $\mathrm{m}^{-3}$ for PRD and $3.02 \mathrm{~kg} \mathrm{~m}^{-3}$ for RDI. These findings are consistent with the studies carried out in other parts of the world (Liu et al., 2006, Shahnazari et al., 2008).

In terms of dry matter, the water productivity for potato under fresh water treatment was 2.75 $\mathrm{kg} \mathrm{m}^{-3}$ for PRD and $2.7 \mathrm{~kg} \mathrm{~m}^{-3}$ for RDI while for treated waste water it was $2.67 \mathrm{~kg} \mathrm{~m}^{-3}$ for PRD and $2.69 \mathrm{~kg} \mathrm{~m}^{-3}$ for RDI. For maize irrigated with fresh water, the productivity was 5.18 $\mathrm{kg} \mathrm{m}^{-3}$ for PRD and $4.82 \mathrm{~kg} \mathrm{~m}^{-3}$ for RDI while for treated waste water irrigation treatment the water productivity was $4.73 \mathrm{~kg} \mathrm{~m}^{-3}$ for PRD and $4.31 \mathrm{~kg} \mathrm{~m}^{-3}$ for RDI.

Overall the water productivity in relation to irrigation strategy showed that the water productivity of PRD is either equal or above the values of RDI. In terms of water quality impact, the water productivity values of fresh and treated waste water were close to each other. These results are also mirrored by the model results. Given that the PRD received $15-17 \%$ less water than RDI and the water productivity values of both PRD and RDI were close for both water qualities, one can conclude that PRD using TWW has the potential to save fresh water and save costs when compared with RDI. 

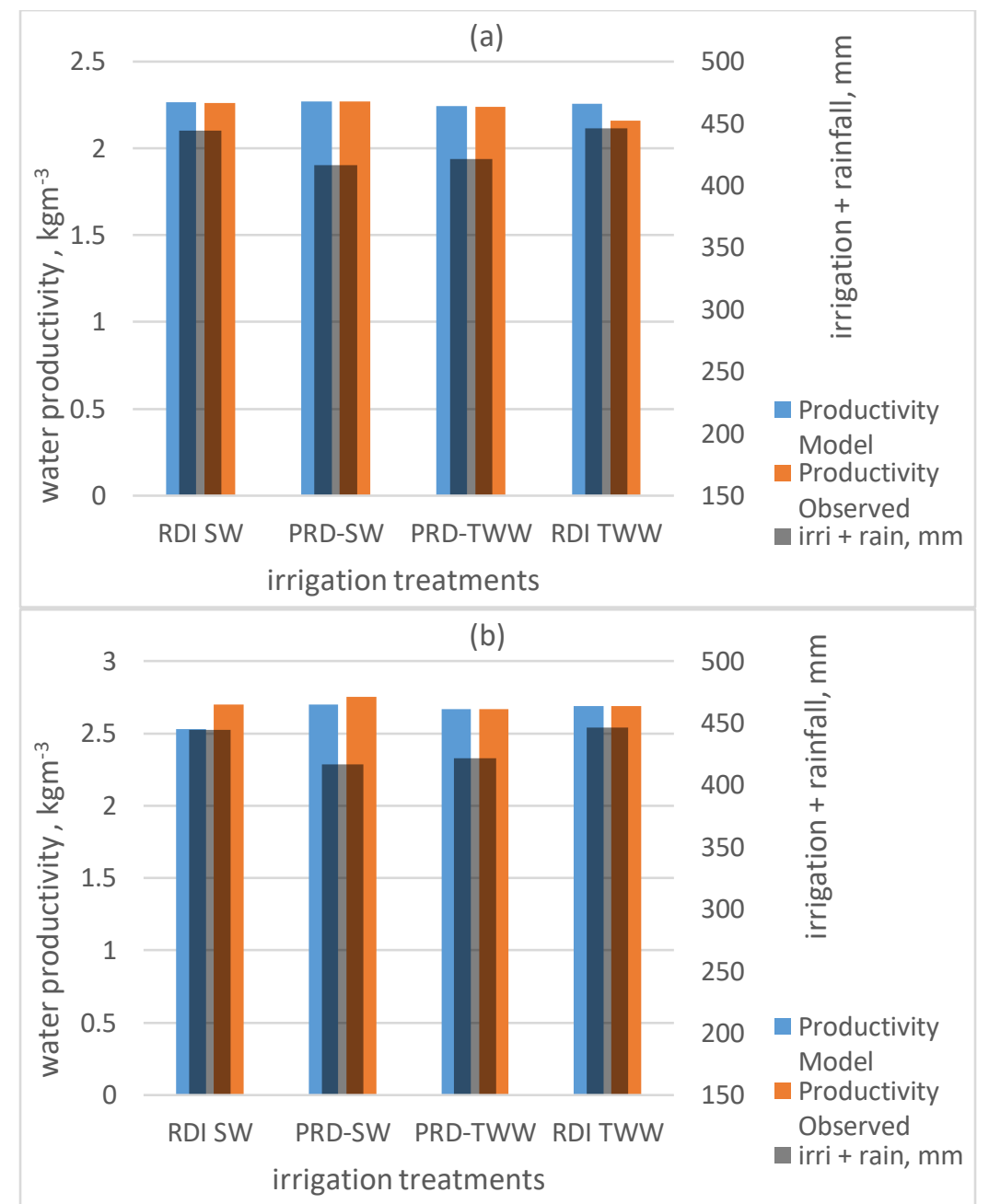

Figure 21. Observed and simulated water productivity for the total yield (a) and total dry matter (b) for potato (2013) and the amount of water supplied. 

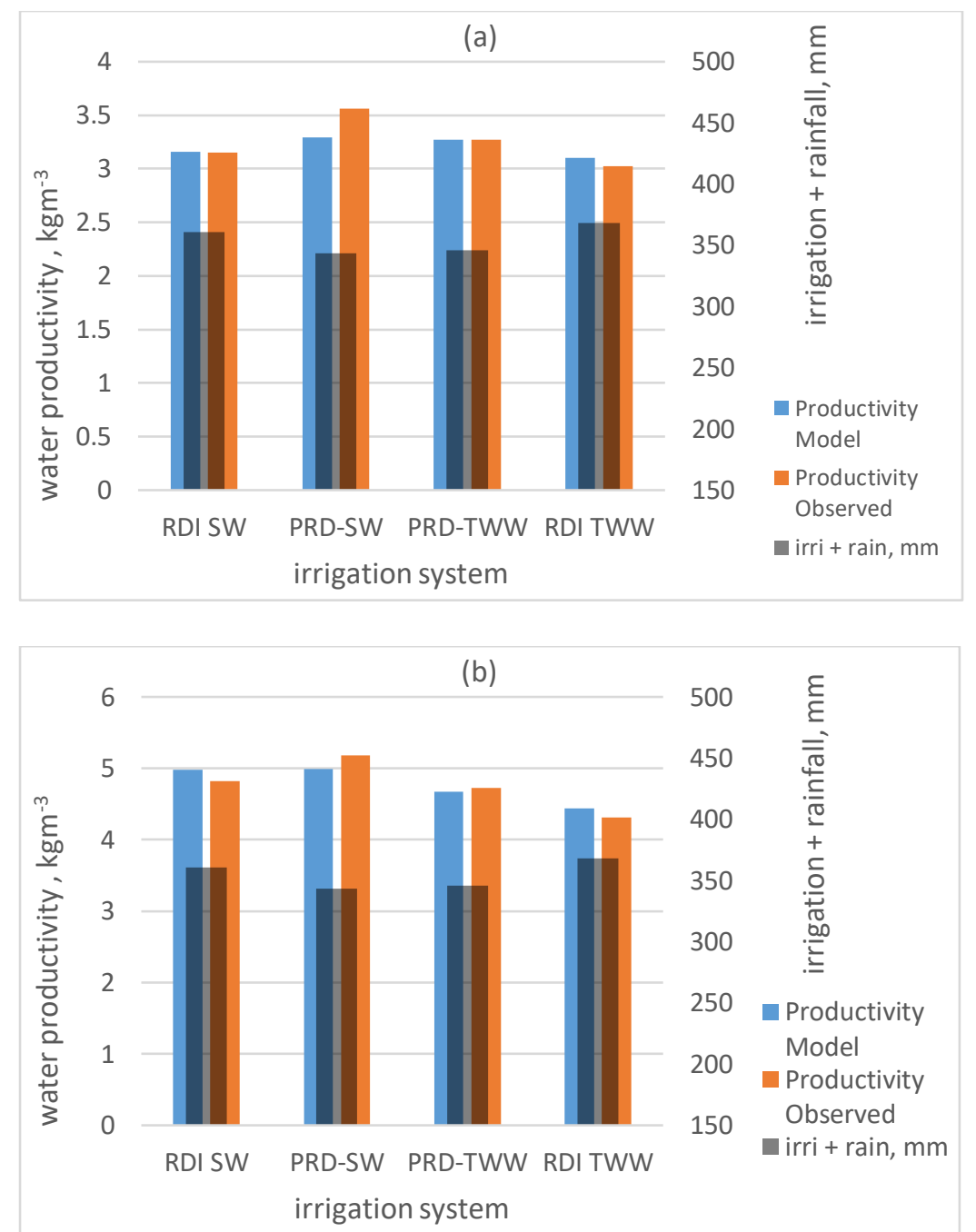

Figure 22. Observed and simulated water productivity for the total yield (a) and total dry matter (b) for maize (2014) and the amount of water supplied. 
Table 2. Observed and simulated (total yield \& total dry matter) for potato and water productivity for the year 2013 in Bologna, Italy

\begin{tabular}{|c|c|c|c|c|c|c|c|c|c|c|c|c|c|}
\hline \multirow[t]{2}{*}{$\begin{array}{l}\text { Irrigation } \\
\text { Treatment }\end{array}$} & \multirow{2}{*}{$\begin{array}{c}\text { Irrigation } \\
\mathrm{mm}\end{array}$} & \multirow{2}{*}{$\begin{array}{l}\text { Rain } \\
\mathrm{mm}\end{array}$} & \multirow{2}{*}{$\begin{array}{l}\begin{array}{l}\text { Irrigation } \\
\text { + rain }\end{array} \\
\mathrm{mm}\end{array}$} & \multicolumn{2}{|c|}{$\begin{array}{l}\text { Yield } \\
\mathrm{t} \mathrm{ha}^{-1}\end{array}$} & \multirow{2}{*}{$\begin{array}{l}\begin{array}{l}\text { Yield } \\
\text { difference } \\
* \\
\%\end{array} \\
\end{array}$} & \multicolumn{2}{|c|}{$\begin{array}{c}\text { Yield water } \\
\text { productivity }\left(\mathrm{kg} \mathrm{m}^{-3}\right)\end{array}$} & \multicolumn{2}{|c|}{$\begin{array}{l}\text { Total dry matter } \\
\qquad \mathrm{t} \mathrm{ha}^{-1}\end{array}$} & \multirow{2}{*}{$\begin{array}{l}\begin{array}{l}\text { Total dry } \\
\text { matter } \\
\text { difference* }\end{array} \\
\%\end{array}$} & \multicolumn{2}{|c|}{$\begin{array}{c}\text { Dry matter water } \\
\text { productivity } \\
\left(\mathrm{kg} \mathrm{m}^{-3}\right)\end{array}$} \\
\hline & & & & Observed & Simulated & & Observed & Simulated & Observed & Simulated & & Observed & Simulated \\
\hline RDI SW & 186.49 & 258 & 444.49 & 10.08 & 10.03 & -0.47 & 2.26 & 2.267 & 11.77 & 11.98 & -1.93 & 2.70 & 2.53 \\
\hline RDI TWW & 188.49 & 258 & 446.49 & 10.08 & 9.85 & -2.29 & 2.16 & 2.257 & 11.73 & 11.99 & -2.31 & 2.69 & 2.69 \\
\hline PRD-SW & 158.49 & 258 & 416.49 & 9.46 & 9.47 & 0.09 & 2.27 & 2.272 & 10.95 & 11.26 & -2.86 & 2.75 & 2.70 \\
\hline PRD-TWW & 163.49 & 258 & 421.49 & 9.46 & 9.46 & -0.07 & 2.24 & 2.245 & 11.01 & 11.26 & -2.31 & 2.67 & 2.67 \\
\hline
\end{tabular}

* Means \% difference between observed and simulated

Table 3. Observed and simulated (total yield \& total dry matter) for maize and water productivity for the year 2014 in Bologna, Italy

\begin{tabular}{|c|c|c|c|c|c|c|c|c|c|c|c|c|c|}
\hline \multirow[t]{2}{*}{$\begin{array}{l}\text { Irrigation } \\
\text { Treatment }\end{array}$} & \multirow{2}{*}{$\begin{array}{c}\text { Irrigation } \\
\mathrm{mm}\end{array}$} & \multirow{2}{*}{$\begin{array}{c}\text { Rain } \\
\mathrm{mm}\end{array}$} & \multirow{2}{*}{$\begin{array}{l}\begin{array}{l}\text { Irrigation } \\
\text { + rain }\end{array} \\
\mathrm{mm}\end{array}$} & \multicolumn{2}{|c|}{$\begin{array}{l}\text { Yield } \\
\mathrm{t} \mathrm{ha}^{-1}\end{array}$} & \multirow{2}{*}{$\begin{array}{l}\text { Yield } \\
\text { difference } \\
* \\
\%\end{array}$} & \multicolumn{2}{|c|}{$\begin{array}{c}\text { Yield water } \\
\text { productivity }\left(\mathrm{kg} \mathrm{m}^{-3}\right)\end{array}$} & \multicolumn{2}{|c|}{$\begin{array}{l}\text { Total dry matter } \\
t_{\text {ha }}^{-1}\end{array}$} & \multirow{2}{*}{\begin{tabular}{l}
$\begin{array}{l}\text { Total dry } \\
\text { matter } \\
\text { difference* }\end{array}$ \\
\multicolumn{1}{c}{$\%$}
\end{tabular}} & \multicolumn{2}{|c|}{$\begin{array}{l}\text { Dry matter water } \\
\text { productivity } \\
\left(\mathrm{kg} \mathrm{m}^{-3}\right)\end{array}$} \\
\hline & & & & Observed & Simulated & & Observed & Simulated & Observed & Simulated & & Observed & Simulated \\
\hline RDI SW & 101.0 & 259 & 360.0 & 11.39 & 11.36 & 0.37 & 3.15 & 3.16 & 17.97 & 17.69 & 0.37 & 4.82 & 4.98 \\
\hline RDI TWW & 103.5 & 259 & 362.5 & 11.35 & 11.26 & 0.03 & 3.02 & 3.11 & 16.13 & 16.35 & -1.61 & 4.31 & 4.44 \\
\hline PRD-SW & 83.8 & 259 & 342.8 & 11.29 & 11.33 & 0.06 & 3.56 & 3.29 & 16.13 & 16.78 & -0.88 & 5.18 & 4.99 \\
\hline PRD-TWW & 86.1 & 259 & 345.1 & 11.29 & 11.28 & -1.10 & 3.27 & 3.27 & 16.13 & 16.35 & 0.27 & 4.73 & 4.67 \\
\hline
\end{tabular}

* Means \% difference between observed and simulated 


\section{General Discussion}

Although the two strategies of irrigation application are based on the concept of deficit irrigation, one can see from the results that the PRD with 15 to $17 \%$ less water than the RDI, produced nearly similar yield. In addition, using two different water qualities did not seem to have a large impact on yield and biomass. These findings were similar between the observed and simulation results. There are some specific model results worth noting here. The SALTMED model was more sensitive to some of the variables, like hydraulic conductivity, initial soil moisture (especially for short period of simulation, e.g. one season) and some crop parameters like $\mathrm{kc}, \mathrm{kb}$ and $\mathrm{FC}$ which are not commonly measured and most of the time are selected from literature. The same findings were also reported by Silva et al. (2013) and Montenegro et al. (2010). In addition, the crop growth in SALTMED depends largely on photosynthetic efficiency. The higher photosynthetic efficiency for the maize than potato during the model calibration showed that SALTMED model can distinguish between C4 and C3 crops as C4 crops, like maize, are known for their higher photosynthetic efficiency. It was also noticed during the soil moisture calibration stage that using different soil horizons with different soil properties and initial soil moisture and salinity contents instead of one homogeneous profile resulted in a better soil moisture calibration. One should also mention that, the model not only showed a good correlation with the observed soil moisture and crop yield but also with the intermediate values of biomass during the growth stages. The simulated soil moisture, crop yield and total dry matter were very close to the observed values. The field experiment and the modelling study suggest that the partial root drying (PRD) and regular deficit irrigation (RDI) irrigation strategies have a huge potential to save irrigation water comparison to the full irrigation. The findings of the study suggest that the treated waste water almost produced similar crop yields in the field experiment and the modelling study. The outcome of this study also suggests that crop water productivity could be increased by implementing more innovative irrigation systems and proper irrigation strategies like partial root drying.

\section{Conclusion}

In comparing two deficit irrigation strategies, RDI and PRD, and two different water qualities, surface fresh water and treated waste water spiked with salt, over two seasonal crops, potato 2013 and maize in 2014, some interesting results were obtained. For maize 2014 season, the PRD strategy received almost $15 \%$ less irrigation water, produced a yield only $6 \%$ less than 
RDI and gave equal water productivity to RDI. Similarly, in 2014, potato received $17 \%$ less irrigation water but produced nearly the same yield as under RDI. The water productivity, on average, was $11 \%$ higher for PRD compared with RDI. Given that the two strategies received the same amount of rainfall the results favour the PRD over RDI. Had the site not received above average rainfall during those two years, PRD might possibly produce much better results.

In terms of model simulations, overall, the model showed a stronger relationship between the observed and the simulated soil moisture and salinity profiles, total dry mater and final yields. This illustrates SALTMED model's ability to simulate the biomass and yield of C3 and C4 crops as well as to simulate different water qualities and different water application strategies. Therefore, the model can run with "what if" scenarios depicting several water qualities, crops and irrigation systems and strategies without the need to try them all in the field. This will reduce costs of labour and investment.

\section{Acknowledgement}

The Water for Crops (W4Cs) project is funded by the European Commission under Grant agreement no: 311933, Theme [KBBE.2012.3.5-03].

\section{References:}

ARSLAN, A., MAJID, G. A., ABDALLAH, K., RAMESHWARAN, P., RAGAB, R., SINGH, M. and QADIR, M. 2015. Evaluating the productivity potential of chickpea, lentil and faba bean under saline water irrigation systems. Irrigation and Drainage.Published online in Wiley Online Library (wileyonlinelibrary.com) DOI: 10.1002/ird.1912

BATTILANI, A., 2006a. Fertirrigere V2.11: A Multi-Target Dss To Manage Water and Nutrients Supply At Macrozone Level. IX ISHS Symposium on Processing Tomato, Melbourne Nov 15-18 2004. Acta Hort. 724:111-118.

BATTILANI, A., PLAUBORG, F., HANSEN, S., ABRAHAMSEN, P. and TOFTENG, C., 2006b. Performance of the FertOrgaNic DSS assessed from comparisons with measured soil water content, $\mathrm{N}$-uptake and estimated N-leaching. EU project FertOrgaNic internal report. http://www.fertorganic.org/Lib/FertOrgaNic/Deliverable/D3_3_D4_3_DSS_performa nce.pdf 
FGHIRE, R., WAHBI, S., ANAYA, F., ISSA ALI, O., BENLHABIB, O. \& RAGAB, R. 2015. Response of quinoa to different water management strategies: field experiments and SALTMED model application results. Irrigation and Drainage, 64, 29-40.

GOLABI, M., NASERI, A. \& KASHKULI, H. 2009. Evaluation of SALTMED model performance in irrigation and drainage of sugarcane farms in Khuzestan province of Iran. J Food Agric Environ, 7, 874-880.

GUPTA, H. V., SOROOSHIAN, S. \& YAPO, P. O. 1999. Status of automatic calibration for hydrologic models: Comparison with multilevel expert calibration. Journal of Hydrologic Engineering, 4, 135-143.

HIRICH, A., CHOUKR-ALLAH, R., RAGAB, R., JACOBSEN, S.-E., EL YOUSSFI, L. \& EL OMARI, H. 2012. The SALTMED model calibration and validation using field data from Morocco. Journal of Materials and Environmental Science, 3, 342-359.

LETEY, J., HOFFMAN, G. J., HOPMANS, J. W., GRATTAN, S. R., SUAREZ, D., CORWIN, D. L., OSTER, J. D., WU, L. \& AMRHEIN, C. 2011. Evaluation of soil salinity leaching requirement guidelines. Agricultural Water Management, 98, 502506.

LIU, F., SHAHNAZARI, A., ANDERSEN, M. N., JACOBSEN, S.-E. \& JENSEN, C. R. 2006. Effects of deficit irrigation (DI) and partial root drying (PRD) on gas exchange, biomass partitioning, and water use efficiency in potato. Scientia Horticulturae, 109, 113-117.

MONTENEGRO, S. G., MONTENEGRO, A. \& RAGAB, R. 2010. Improving agricultural water management in the semi-arid region of Brazil: experimental and modelling study. Irrigation Science, 28, 301-316.

PULVENTO, C., ARICCARDI, M., LAVINI, A., D'ANDRIA, R. \& RAGAB, R. 2015a. Parameterization and field validation of SALTMED Model for grain amaranth tested in South Italy. Irrigation and Drainage, 64, 59-68.

PULVENTO, C., LAVINI, A., RICCARDI, M., D'ANDRIA, R. \& RAGAB, R. 2015b. Assessing Amaranth Adaptability in a Mediterranean Area of South Italy under Different Climatic Scenarios. Irrigation and Drainage, 64, 50-58.

PULVENTO, C., RICCARDI, M., LAVINI, A., D'ANDRIA, R. \& RAGAB, R. 2013.

SALTMED model to simulate yield and dry matter for quinoa crop and soil moisture content under different irrigation strategies in south Italy. Irrigation and Drainage, 62, 229-238. 
RAGAB, R. 2002. A holistic generic integrated approach for irrigation, crop and field management: the SALTMED model. Environmental Modelling \& Software, 17, 345361.

RAGAB, R. 2015. Integrated Management Tool for Water, Crop, Soil and N-Fertilizers: The Saltmed Model. Irrigation and Drainage, 64, 1-12.

RAGAB, R., BATTILANI, A., MATOVIC, G., STIKIC, R., PSARRAS, G. \& CHARTZOULAKIS, K. 2015. SALTMED Model as an Integrated Management Tool for Water, Crop, Soil and N-Fertilizer Water Management Strategies and Productivity: Field and Simulation Study. Irrigation and Drainage, 64, 13-28.

RAGAB, R., MALASH, N., GAWAD, G. A., ARSLAN, A. \& GHAIBEH, A. 2005a. A holistic generic integrated approach for irrigation, crop and field management: 1 . The SALTMED model and its calibration using field data from Egypt and Syria. Agricultural water management, 78, 67-88.

RAGAB, R., MALASH, N., GAWAD, G. A., ARSLAN, A. \& GHAIBEH, A. 2005b. A holistic generic integrated approach for irrigation, crop and field management: 2 . The SALTMED model validation using field data of five growing seasons from Egypt and Syria. Agricultural water management, 78, 89-107.

RAMESHWARAN, P., TEPE, A. \& RAGAB, R. 2015. The effect of saline irrigation water on the yield of pepper: experimental and modelling study. Irrigation and Drainage, 64, 41-49.

RAZZAGHI, F., PLAUBORG, F., AHMADI, S. H., JACOBSEN, S.-E., ANDERSEN, M. N. \& RAGAB, R. 2013. Simulation of Quinoa (Chenopodium Quinoa Wild) response to soil salinity using the SALTMED model in Denmark. SWUP-MED Project, 30.

SHAHNAZARI, A., AHMADI, S. H., LAERKE, P. E., LIU, F., PLAUBORG, F., JACOBSEN, S.-E., JENSEN, C. R. \& ANDERSEN, M. N. 2008. Nitrogen dynamics in the soil-plant system under deficit and partial root-zone drying irrigation strategies in potatoes. European Journal of Agronomy, 28, 65-73.

SILVA, L., RAGAB, R., DUARTE, I., LOURENÇO, E., SIMÕES, N. \& CHAVES, M. 2013. Calibration and validation of SALTMED model under dry and wet year conditions using chickpea field data from Southern Portugal. Irrigation Science, 31, 651-659.

TILMAN, D., CASSMAN, K. G., MATSON, P. A., NAYLOR, R. \& POLASKY, S. 2002. Agricultural sustainability and intensive production practices. Nature, 418, 671-677. 